 UNIVERSITY OF TECHNOLOGY
}

\section{Extraction of copper(II) and nickel(II) by cyclic trioximes and cyclic furazan oximes}

\section{Citation for published version (APA):}

Paping, L. R. M., Beelen, T. P. M., Mols, M., \& Prins, R. (1984). Extraction of copper(II) and nickel(II) by cyclic trioximes and cyclic furazan oximes. Polyhedron, 3(4), 479-484. https://doi.org/10.1016/S0277-5387(00)84522-2

DOI:

10.1016/S0277-5387(00)84522-2

Document status and date:

Published: 01/01/1984

\section{Document Version:}

Publisher's PDF, also known as Version of Record (includes final page, issue and volume numbers)

\section{Please check the document version of this publication:}

- A submitted manuscript is the version of the article upon submission and before peer-review. There can be important differences between the submitted version and the official published version of record. People interested in the research are advised to contact the author for the final version of the publication, or visit the $\mathrm{DOI}$ to the publisher's website.

- The final author version and the galley proof are versions of the publication after peer review.

- The final published version features the final layout of the paper including the volume, issue and page numbers.

Link to publication

\section{General rights}

Copyright and moral rights for the publications made accessible in the public portal are retained by the authors and/or other copyright owners and it is a condition of accessing publications that users recognise and abide by the legal requirements associated with these rights.

- Users may download and print one copy of any publication from the public portal for the purpose of private study or research.

- You may not further distribute the material or use it for any profit-making activity or commercial gain

- You may freely distribute the URL identifying the publication in the public portal.

If the publication is distributed under the terms of Article $25 \mathrm{fa}$ of the Dutch Copyright Act, indicated by the "Taverne" license above, please follow below link for the End User Agreement:

www.tue.nl/taverne

Take down policy

If you believe that this document breaches copyright please contact us at:

openaccess@tue.nl

providing details and we will investigate your claim. 


\title{
EXTRACTION OF COPPER(II) AND NICKEL(II) BY CYCLIC TRIOXIMES AND CYCLIC FURAZAN OXIMES
}

\author{
L. R. M. PAPING, T. P. M. BEELEN, M. MOLS and R. PRINS* \\ Laboratory of Inorganic Chemistry, Eindhoven University of Technology, P.O. Box 513, \\ 5600 MB Eindhoven, The Netherlands
}

(Received 25 August 1983; accepted 1 November 1983)

\begin{abstract}
The extraction properties of 1,2,3-cyclopentanetrione trioxime $\left(\mathrm{H}_{3} \mathrm{CPT}\right)$ and its furazan, and of 4-t-butyl-1,2,6-cyclohexanetrione trioxime $\left(\mathrm{H}_{3} \mathrm{BHT}\right)$ and its furazan are described. $\mathrm{H}_{3} \mathrm{CPT}$ was found to be too soluble in water and was therefore of no use in extraction but $\mathrm{H}_{3} \mathrm{BHT}$ was satisfactory. The extracted copper and nickel chelates of $\mathrm{H}_{3} \mathrm{BHT}$ precipitate by agglomeration caused by intermolecular hydrogen bonding and/or coordination of the third oxime group. This precipitation blocked back extraction. The furazan oximes derived from these trioximes did not form copper or nickel chelates under extraction conditions.
\end{abstract}

In order to find an extractant that is selective for nickel with respect to copper a number of organic compounds have been synthesized and studied for their extraction properties. Because of the great affinity of nickel for dioximes this investigation is limited to organic groups containing oxime groups. From previous work ${ }^{1,2}$ it became clear that the use of strained instead of unstrained dioximes makes the extraction more convenient because of a higher extraction rate, but the selectivity for nickel above copper disappears. In this article two new kinds of ligands will be examined, viz. the cyclic trioximes (Fig. 1) and the cyclic furazan oximes (Fig. 2).

Frierson and Marable $^{3}$ discovered that 1,2,3-cyclohexanetrione trioxime instantaneously forms a $\mathrm{NiL}_{2}$ chelate with nickel(II) salts in an ethanol/water mixture but they did not investigate the extraction capacities. They postulated a $\mathrm{NiN}_{2} \mathrm{O}_{2}$ chromophore to be formed which is unexpected because there is not much strain in the cyclic hexane ring. Furthermore, it is unknown what the influence will be of the third oxime group on the stability of the copper and nickel chelates, because now additional hydrogen bridging is possible. This makes the cyclic trioximes very interesting to study. Besides, the cyclic trioxime is a precursor of the cyclic furazan oxime. In previous work ${ }^{2}$ it was found that nopinoquinone dioxime could easily be converted into a furazan, but this furazan was not active in extraction, probably because no
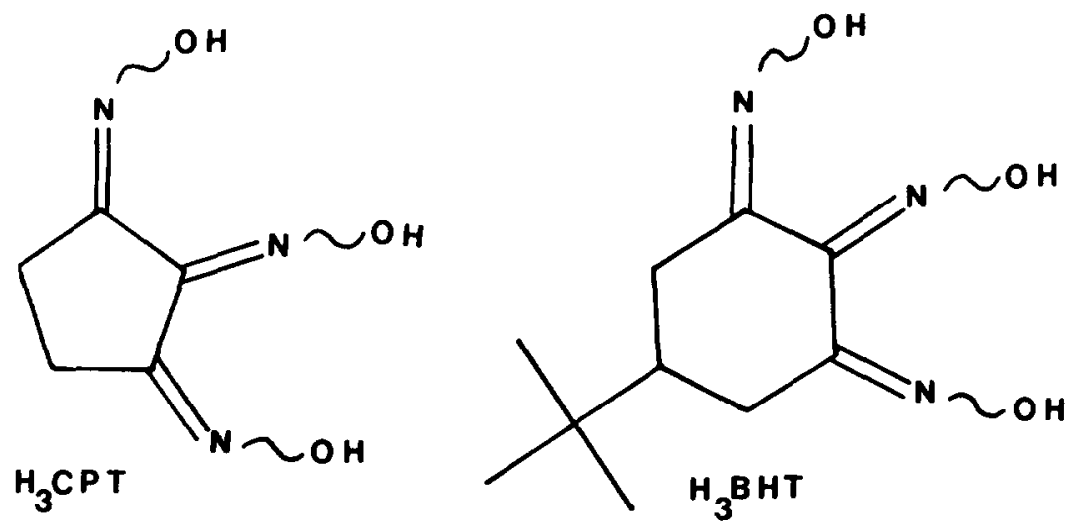

Fig. 1. Schematic structures of 1,2,3-cyclopentanetrione trioxime $\left(\mathrm{H}_{3} \mathrm{CPT}\right)$ and $4-t$-butyl-1,2,6cyclohexanetrione trioxime $\left(\mathrm{H}_{3} \mathrm{BHT}\right)$. 


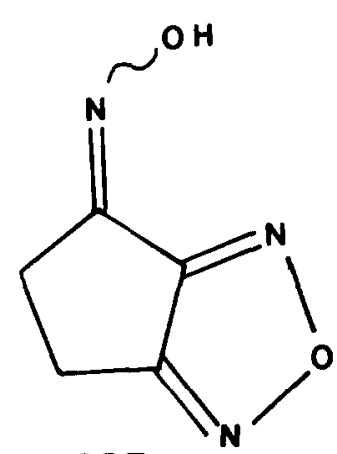

HF CPT

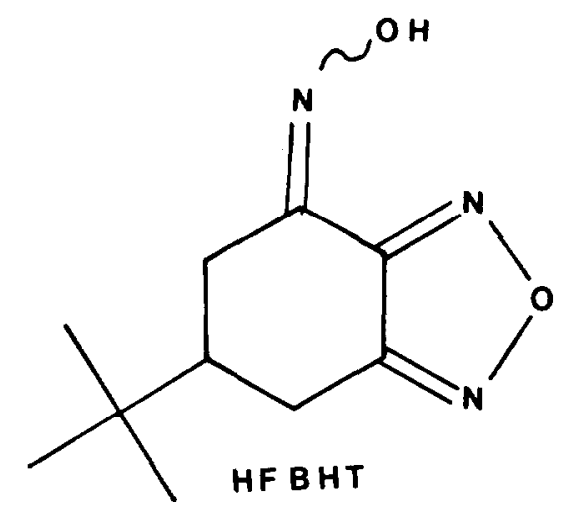

Fig. 2. Schematic structures of the furazan derived from 1,2,3-cyclopentanetrione trioxime (HFCPT) and the furazan derived from 4-t-butyl-1,2,6-cyclohexanetrione trioxime (HFBHT).

acidic hydrogen atom is present. The cyclic furazan oxime has such an acidic hydrogen and furthermore this molecule can react as a bidentate ligand.

For these reasons 1,2,3-cyclopentanetroine trioxime $\left(\mathrm{H}_{3} \mathrm{CPT}\right)$ and 4- $t$-butyl-1,2,6-cyclohexanetrione trioxime $\left(\mathrm{H}_{3} \mathrm{BHT}\right)$ were synthesized and examined. In addition, these two trioximes were converted into the furazan of 1,2,3-cyclopentanetrione trioxime (HFCPT) and the furazan of 4- $t$-butyl-1,2,6-cyclohexanetrione trioxime (HFBHT).

\section{EXPERIMENTAL}

${ }^{1} \mathrm{H}$ NMR spectra were obtained at room temperature on a $60 \mathrm{MHz}$ Varian EM $360 \mathrm{~A}$ spectrometer, while ESR measurements were made with a Varian E15 spectrometer at room temperature and UV-visible spectra were obtained on a Unicam Sp. 800D. Aqueous metal ion concentrations were measured with the Perkin-Elmer 300 Atomic Absorption Spectrophotometer.

The extraction experiments were carried out in a three stoppered flask with a stirring device and continuous $\mathrm{pH}$ measurements. The starting volumes of water and organic solvent were both $250 \mathrm{~cm}^{3}$. Stirring was stopped when no further change of the $\mathrm{pH}$ was noticed, indicating that equilibrium was reached. For analysis equally small volumes of water layer and organic layer were withdrawn from the system. To measure the distribution coefficient as a function of $\mathrm{pH}$ thereafter a small quantity of $4 \mathrm{~N}$ acid or base was added, and the process of stirring until equilibrium and withdrawal of small portions of the aqueous and organic solutions was repeated at a different $\mathrm{pH}$. Care was taken to keep the volumes of the aqueous and organic solutions equal. Although in this procedure the electrolyte concentration does not stay constant we preferred this method because it is convenient to execute and because in a sepa- rate experiment it was shown that in the applied concentration range the influence of the electrolyte concentration is negligible. Pentanol was used as organic solvent and as inorganic salt we used metal nitrate. We used $\mathrm{NaOH}$ as base and $\mathrm{HNO}_{3}$ as acid.

\section{SYNTHESIS}

\section{1,2,3-Cyclopentanetrione trioxime $\left(\mathrm{H}_{3} \mathrm{CPT}\right)$}

Following the method of Ferris ${ }^{4}$ using $n$ butylnitrite crude 1,2,3-cyclopentanetrione 1,3-dioxime was obtained as a brown compound from cyclopentanone (E. Merck A. G., Darmstadt, zur synthese).

IR: $1725 \mathrm{~cm}^{-1} \quad(\mathrm{C}=\mathrm{O})$; and new bands at $1625 \mathrm{~cm}^{-1}(\mathrm{C}=\mathrm{N})$ and $3250 \mathrm{~cm}^{-1}$ broad $(\mathrm{OH})$.

The crude trione dioxime was dissolved in ethanol and treated with an aqueous solution of $\mathrm{NH}_{2} \mathrm{OH} \cdot \mathrm{HCl}$ and $\mathrm{NaOAc}$ under reflux. The product was washed with ethanol and extracted with boiling ethanol and after that washed with water. A brown product was obtained in small quantity (because of the good solubility in water) which could not be decolourized. Found: C, 36.67; H, $4.23 ; \mathrm{N}, 27.06$. Calc. for $\mathrm{C}_{5} \mathrm{H}_{7} \mathrm{~N}_{3} \mathrm{O}_{3}: \mathrm{C}, 38.22 ; \mathrm{H}$, $4.49 ; \mathrm{N}, 26.74 \%$.

IR: $1725 \mathrm{~cm}^{-1}(\mathrm{C}=\mathrm{O})$ disappeared; $1625 \mathrm{~cm}^{-1}$ broad absorption $(\mathrm{C}=\mathrm{N})$ and $3300 \mathrm{~cm}^{-1}$ broad absorption.

\section{The furazan of 1,2,3-cyclopentanetrione trioxime (HFCPT)}

Crude 1,2,3-cyclopentanetrione 1,3-dioxime $(0.07 \mathrm{~mol})$ (see synthesis $\mathrm{H}_{3} \mathrm{CPT}$ ) dissolved in a solution of $0.3 \mathrm{~mol} \mathrm{NaOH}$ in $50 \mathrm{~cm}^{3}$ water was treated with a solution of $\mathrm{NH}_{2} \mathrm{OH} \cdot \mathrm{HCl}(0.18 \mathrm{~mol})$ in $75 \mathrm{~cm}^{3}$ water during several days at $60^{\circ} \mathrm{C}$. After filtration the filtrate was acidified till $\mathrm{pH}=2$ and filtered. The filtrate was extracted with ether and evaporating the ether layer after drying $\left(\mathrm{Na}_{2} \mathrm{SO}_{4}\right)$ gave $1 \mathrm{~g}$ of a ycllow solid. Found: C, 43.22; H, 
3.90; N, 30.11. Calc. for $\mathrm{C}_{5} \mathrm{H}_{5} \mathrm{~N}_{3} \mathrm{O}_{2}: \mathrm{C}, 43.17 ; \mathrm{H}$, $3.62 ; \mathrm{N}, 30.21 \%$.

IR $3300 \mathrm{~cm}^{-1}$ sharp (OH), $1520 \mathrm{~cm}^{-1}$ (furazan) $1600-1650 \mathrm{~cm}^{-1}$ broad $(\mathrm{C}=\mathrm{N})$.

\section{4-t-butyl-1,2,6-cyclohexanetrione trioxime $\left(\mathrm{H}_{3} \mathrm{BHT}\right)$}

Following the method of Ferris ${ }^{4}$ using $n$-butylnitrite crude 4- $t$-butyl-1,2,6-trione-2,6-dioxime was obtained as a light brown compound from 4- $t$-butylcyclohexanon (Janssen Chimica, Beerse, Belgium, 95+\%). Found: C, 56.19; H, 7.51; N, 12.92. Calc. for $\mathrm{C}_{10} \mathrm{H}_{16} \mathrm{~N}_{2} \mathrm{O}_{3}: \mathrm{C}, 56.60 ; \mathrm{H}, 7.55 ; \mathrm{N}$, $13.21 \%$.

IR: $3230 \mathrm{~cm}^{-1}$ broad (OH), 1620 and $1590 \mathrm{~cm}^{-1}$ $(\mathrm{C}=\mathrm{N})$ as new absorptions, $1710 \mathrm{~cm}^{-1}(\mathrm{C}=\mathrm{O})$.

Crude 4- $t$-butyl-1,2,6-trione 2,6-dioxime was converted into $\mathrm{H}_{3} \mathrm{BHT}$ by the same method as for $\mathrm{H}_{3}$ CPT. The reaction mixture was filtered and the filtrate was evaporated. The solid thus obtained was washed with ethylacetate resulting in a white product. Found: $\mathrm{C}, 53.00 ; \mathrm{H}, 7.66 ; \mathrm{N}, 18.77$. Calc. for $\mathrm{C}_{10} \mathrm{H}_{17} \mathrm{~N}_{3} \mathrm{O}_{3}: \mathrm{C}, 52.86 ; \mathrm{H}, 7.49 ; \mathrm{N}, 18.50 \%$. IR: $3230 \mathrm{~cm}^{-1}$ broad (OH), $1650,1610,1580 \mathrm{~cm}^{-1}$ weak $(\mathrm{C}=\mathrm{N})$; the $\mathrm{C}=\mathrm{O}$ absorption at $1710 \mathrm{~cm}^{-1}$ had disappeared. ${ }^{1} \mathrm{H}$ NMR DMSO-d6: $\delta 0.9$ (s, 9H), $\delta 1.6-3.2$ (m.c, 5H), $\delta 11.4,11.7$ en 12.6 (s, $\mathrm{OH})$.

The furazan of 4-t-butyl-1,2,6-cyclohexanetrione trioxime (HFBHT)

Crude 4 - $t$ - butyl - 1,2,6 - cyclohexanetrione 2,6 - dioxime (see synthesis $\mathrm{H}_{3} \mathrm{BHT}$ ) was converted into the furazan of $\mathrm{H}_{3} \mathrm{BHT}$ by using the same method as for the synthesis of HFCPT. The reaction mixture was filtered and acidified till $\mathrm{pH}=7$. The solid thus obtained was filtered, washed with water and dried with silica to yield a white product. Found: $\mathrm{C}, 57.15 ; \mathrm{H}, 7.33 ; \mathrm{N}, 19.93$. Calc. for $\mathrm{C}_{10} \mathrm{H}_{15} \mathrm{~N}_{3} \mathrm{O}_{2}: \mathrm{C}, 57.42 ; \mathrm{H}, 7.18 ; \mathrm{N}, 20.10 \%$.

IR: $3290 \mathrm{~cm}^{-1}$ sharp (OH); 1635 and $1582 \mathrm{~cm}^{-1}(\mathrm{C}=\mathrm{N}), 1510 \mathrm{~cm}^{-1}$ (furazan). ${ }^{1} \mathrm{H}$ NMR DMSO-d6: $\delta 0.9(\mathrm{~s}, 9 \mathrm{H}), \delta$ 1.6-3.5 (m.c, $5 \mathrm{H}), \delta 12.1$ (s, OH).

\section{RESULTS}

$\mathrm{H}_{3} \mathrm{CPT}$ appeared to be fairly soluble in water. The only organic solvent in which we could dissolve $\mathrm{H}_{3} \mathrm{CPT}$ was tri- $n$-butyl phosphate (tbp) but when this solution was mixed with water the $\mathrm{H}_{3} \mathrm{CPT}$ was transported to the water layer. When adding metal sulphates the copper and nickel chelates formed were not transported to the or- ganic layer, but precipitated in the water layer. The isolated brown copper chelate had an elemental analysis of C, 27.26; H. 2.55; N, 17.69; Cu, 19.34\%. The isolated red brown nickel chelate had an elemental analysis of $\mathrm{C}, 28.78 ; \mathrm{H}, 3.02 ; \mathrm{N}, 18.48$; $\mathrm{Ni}, 17.21 \%$. No ESR signal could be measured for this copper chelate, while the NMR spectrum of the nickel chelate could not be obtained because of its insolubility in organic solvents.

HFCPT dissolved very well in tbp, pentanol, ether and water but it possessed no extraction capacity for $\mathrm{Cu}(\mathrm{II})$ and $\mathrm{Ni}(\mathrm{II})$.

$\mathrm{H}_{3} \mathrm{BHT}$ dissolved very well in pentanol and only slightly in water. Extraction experiments in pentanol with $\mathrm{Ni}$ (II) gave a fine red precipitate in the organic layer. At $\mathrm{pH}=2.8699 .4 \%$ of the nickel was extracted, when using $0.025 \mathrm{~mol} / 1 \mathrm{H}_{3} \mathrm{BHT}$ in pentanol and $0.002 \mathrm{~mol} / 1 \mathrm{Ni}\left(\mathrm{NO}_{3}\right)_{2}$ in water with equal volumes. Equilibrium was reached in about $1 \mathrm{hr}$. Back extraction could not be observed down to $\mathrm{pH}=1$. The isolated nickel chelate had an elemental analysis of $\mathrm{C}, 47.74 ; \mathrm{H}, 6.52 ; \mathrm{N}, 16.60$; $\mathrm{Ni}, 10.67 \%$ which points in the direction of a $\mathrm{Ni}\left(\mathrm{H}_{2} \mathrm{BHT}\right)_{2}$ chelate: Calc. for $\mathrm{NiC}_{20} \mathrm{H}_{32} \mathrm{~N}_{6} \mathrm{O}_{6}: \mathrm{C}$, $46.99 ; \mathrm{H}, 6.50 ; \mathrm{N}, 16.45 ; \mathrm{Ni}, 11.49 \%$.

The extraction of a $0.001 \mathrm{~mol} / 1 \mathrm{Cu}\left(\mathrm{NO}_{3}\right)_{2}$ solution in water by $0.025 \mathrm{~mol} / 1 \mathrm{H}_{3} \mathrm{BCT}$ in pentanol gave the same results as with $\mathrm{Ni}^{2+}$ : a light brown suspension in the organic layer at $\mathrm{pH}=2.91$ and no back extraction till $\mathrm{pH}=1$. The isolated copper chelate had an elemental analysis of $\mathrm{C}, 45.41 ; \mathrm{H}$, $6.12 ; \mathrm{N}, 15.91 ; \mathrm{Cu}, 12.15 \%$ which is in good agreement with a $\mathrm{Cu}\left(\mathrm{H}_{2} \mathrm{BHT}\right)_{2} \cdot 2 \mathrm{H}_{2} \mathrm{O}$ chelate. Calc. for $\mathrm{CuC}_{20} \mathrm{H}_{36} \mathrm{~N}_{6} \mathrm{O}_{8}: \mathrm{C}, 44.99 ; \mathrm{H}, 6.37 ; \mathrm{N}$, $15.75 ; \mathrm{Cu}, 11.90 \%$.

No proper solvent could be found to enable an ESR solution spectrum to be measured. A "powder" ESR spectrum from this compound was not recorded, because in such a spectrum anisotropy will not be averaged out (see (5)) and therefore it is unlikely that the total number of nitrogen atoms coordinated to the copper can be established.

An extraction experiment with excess $\mathrm{Cu}^{2+}$ gave a surprising effect. The organic layer became dark brown and the suspension disappeared. The filtered organic layer was evaporated which yielded a dark brown solid with an elemental analysis of C, 40.07; H, 5.25; N, 17.74; Cu, 19.04\%, which is not completely in agreement with a $\mathrm{Cu}_{n}(\mathrm{HBHT})_{n} \cdot 2 n \mathrm{H}_{2} \mathrm{O}$ chelate: Calc. $\mathrm{Cu}, 20.72 ; \mathrm{C}$, $39.15 ; \mathrm{H}, 5.55 ; \mathrm{N}, 13.70 \%$. No ESR signal could be detected for this chelate in solution at room temperature.

HFBHT was very soluble in organic solvents, but did not possess extraction capacities for $\mathrm{Cu}$ (II) or $\mathrm{Ni}(\mathrm{II})$. 


\section{DISCUSSION}

\section{1,2,3-cyclopentanetrione trioxime $\left(\mathrm{H}_{3} \mathrm{CPT}\right)$}

$\mathrm{H}_{3} \mathrm{CPT}$ is fairly soluble in water. The origin of this behaviour is that the three oxime groups, which can form hydrogen bridges with water, make the molecule hydrophilic, and that the relatively small organic part $\left(-\mathrm{CH}_{2}-\mathrm{CH}_{2}-\right)$ causes only a small hydrophobic effect. The relatively small organic part and the large polarity, caused by the three oxime groups, make this ligand almost insoluble in organic solvents, which do not form homogeneous solutions with water. The $\mathrm{H}_{3} \mathrm{CPT}$ ligand will therefore be of limited value as an extractant, because most of the $\mathrm{H}_{3} \mathrm{CPT}$ will be transported to the water layer, which will lead to undesired ligand losses. Furthermore, the chelates formed with $\mathrm{Cu}(\mathrm{II})$ and $\mathrm{Ni}(\mathrm{II})$ are not transported to the organic layer but precipitate in the water layer. It is therefore recommended to use branched cyclic rings to enlarge the organic hydrophobic part. In that way the resulting ligand will be more soluble in organic solvents and less in water. The elemental analysis of the copper $\mathrm{H}_{3} \mathrm{CPT}$ chelate shows that if a $\mathrm{Cu}: \mathrm{H}_{3} \mathrm{CPT}=1: 2$ chelate is formed at all, it is not the only chelate. The $\mathrm{Cu}: \mathrm{C}=1: 7.5$ ratio and the $\mathrm{Cu}: \mathrm{N}=1: 4.15$ ratio point in the direction of $\mathrm{Cu}: \mathrm{L}=2: 3$ chelate.

The fact that no ESR spectrum is observed, which can be explained by a copper-copper interaction, confirms the hypothesis that at least one copper ion is present nearby each copper (II). For the nickel $\mathrm{H}_{3} \mathrm{CPT}$ chelate almost the same values are observed as for $\mathrm{Cu}: \mathrm{Ni}: \mathrm{C}=1: 8.2$ and $\mathrm{Ni}: \mathrm{N}=1: 4.5$. So here also a $\mathrm{Ni}: \mathrm{L}=2: 3$ molecule is the most probable chelate. The $\mathrm{C}: \mathrm{N}=5: 2.78$ ratio in both chelates shows that some oxime must be lost. Too low hydrogen values (2.55 and 3.02) and the high other values $(100 \%-\mathrm{Cu}-\mathrm{C}-\mathrm{H}-\mathrm{N}=33.16 \%, \quad 100 \%-\mathrm{Ni}-\mathrm{C}-\mathrm{H}-$ $\mathbf{N}=32.51 \%$ ) are pointing in the direction of some inorganic part. Therefore no great significance must be given to the composition of these chelates in relation to extraction chemistry.

\section{The furazan of 1,2,3-cyclopentanetrione trioxime (HFCPT)}

HFCPT can also be called 3,4-trimethylene furazan-6-oxime in analogy with the furazan oxide of Barnes. ${ }^{6}$ This ligand is more soluble in organic solvents than $\mathrm{H}_{3} \mathrm{CPT}$ because two of the three polar oxime groups have now formed an organic aromatic furazan ring. The fact that no extraction capacities were found for this ligand is not surprising when we look at a molecular model of the ligand. The estimated $\mathrm{N}-\mathrm{N}$ distance is about $3.2 \AA$, which is far too large for $\mathrm{N}, \mathrm{N}$-coordination and also makes N,O-coordination unattractive. It cannot be excluded that other furazan oximes with a smaller N-N distance may be good extractants for nickel and copper. If we compare HFCPT with $\mathrm{H}_{3} \mathrm{CPT}$ we can conclude that the solubility capacities have improved, but that the chelating capacities have disappeared.

\section{4-t-butyl-1,2,6-cyclohexanetrione trioxime $\left(\mathrm{H}_{3} \mathrm{BHT}\right)$}

The solubility properties of $\mathrm{H}_{3} \mathrm{BHT}$ for extraction are much better than those of $\mathrm{H}_{3} \mathrm{CPT}$. Differences between $\mathrm{H}_{3}$ BHT and $\mathrm{H}_{3} \mathrm{CPT}$ are the increase of the carbon ring by one carbon atom and the $t$-butyl group. We suggest that most of the increased solubility originates from the large $t$ butyl group which makes the molecule hydrophobic. It is unlikely that enlargement of the ring with only one atom can cause such a change. $\mathrm{H}_{3} \mathrm{CPT}$ has a good extraction capacity $(99.4 \%$ extraction at $\mathrm{pH}=2.86$ ) for nickel, but the extracted chelate was not soluble in the organic layer and precipitated in this phase. The reason for the precipitation in the organic layer (the pentanol layer is the upper phase, the water layer the lower phase) instead of in the water layer must be the strong hydrophobic effect of the $t$-butyl group. Because no such insolubility has been found for the bis(cyclohexaneglyoximato) nickel(II) chelate ${ }^{7}$ the reason for the precipitation must be the third oxime group of $\mathrm{H}_{3} \mathrm{BHT}$. Elemental analysis showed that presumably a $\mathrm{Ni}\left(\mathrm{H}_{2} \mathrm{BHT}\right)_{2}$ chelate is formed, which means that the third oxime group is likely to be involved in intermolecular coordination or hydrogen bridge formation between chelate molecules. As a result the chelate molecules agglomerate and precipitate. This precipitation also means that the extraction is no longer an equilibrium reaction, but a termination reaction. The back extraction is blocked, so the only way to free the nickel ions again is to break the chelate with strong acids, but these acids will also attack and possibly destroy the ligand. As a result this ligand is unattractive for use in a continous process.

The estimated N-N distance of $2.8 \AA$ for $\mathrm{H}_{3} \mathrm{BHT}$ is comparable with that of $\beta-\mathrm{H}_{2} \mathrm{NQD}$ (see (2)), which formed $\mathrm{N}, \mathrm{N}$-coordinated chelates. The red colour of $\mathrm{Ni}\left(\mathrm{H}_{2} \mathrm{BHT}\right)_{2}$ is also found for unstrained aliphatic dioxime nickel chelates and $\mathrm{Ni}(\beta \text {-HNQD })_{2}$, while $\mathrm{N}, \mathrm{O}$-coordinated chelates, like $\mathrm{Ni}(\alpha-\mathrm{HCQD})_{2}$ and $\mathrm{Ni}(\delta \text {-HCQD })_{2}$, are green. ${ }^{8,9}$ This makes $\mathrm{N}, \mathrm{N}$-coordination the most reasonable structure, rather than N,O-coordination as suggested by Frierson and Marable. ${ }^{3}$ In Fig. 3 some possible structures are presented. 

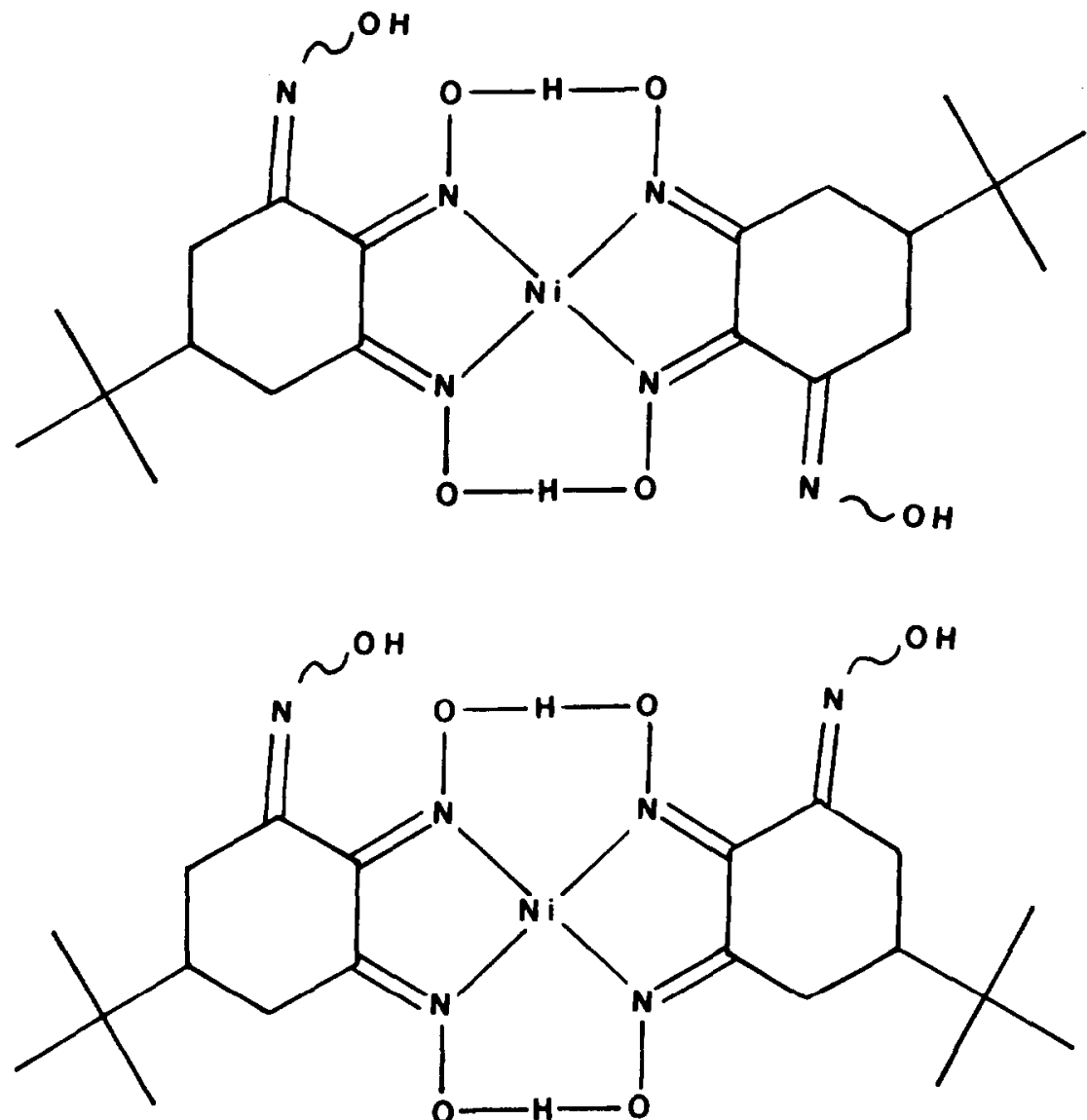

Fig. 3. Two possible structures of the $\mathrm{Ni}\left(\mathrm{H}_{2} \mathrm{BHT}\right)_{2}$ chelate assuming $\mathrm{N}, \mathrm{N}$-coordination.

The copper extraction by $\mathrm{H}_{3} \mathrm{BHT}$ in pentanol gives the same picture as the nickel extraction when excess $\mathrm{H}_{3} \mathrm{BHT}$ is used. Elemental analysis showed that $\mathrm{Cu}\left(\mathrm{H}_{2} \mathrm{BHT}\right)_{2} 2 \mathrm{H}_{2} \mathrm{O}$ precipitated in the organic layer. This means that probably copper forms a distorted octahedral chelate with two additional waters in the axial position, while nickel forms a square planar chelate. This is in analogy with $\beta-\mathrm{H}_{2} \mathrm{NQD}$ chelates (see (2)). "Powder" ESR spectroscopy can perhaps confirm that the copper ion has an octahedral environment. ${ }^{10}$

When using excess copper in the extraction a new chelate is formed that is soluble in the organic layer. From the elemental analysis of the isolated chelate the ratio's $\mathrm{Cu}: \mathrm{C}=1: 11.1$ and $\mathrm{Cu}: \mathrm{N}=1: 3.51$ are calculated. This means that a $\mathrm{Cu}: \mathrm{L}=1: 1$ chelate is formed $(\mathrm{Cu}: \mathrm{C}=1: 10$ and $\mathrm{C}: \mathrm{N}=1: 3$ ) presumably with some organic impurities. The solubility of this chelate in the organic layer can now be explained by the fact that the third oxime group is involved in the chelation with copper, and therefore is no longer available for intermolecular hydrogen bridge formation or intermolecular coordination. The fact that no ESR spectrum can be found for this chelate points in the direction of a strong antiferromagnetic coupling between at least two copper ions, which is well known for binuclear copper complexes. ${ }^{11-14}$ The chelate must be of the type $\mathrm{Cu}_{n} \mathrm{~L}_{n}$ (with $n=$ even).

The phenomenon that with excess copper different chelates are formed was also observed with $\delta-\mathrm{H}_{2} \mathrm{NQD}$ (see (1)) where a $\mathrm{Cu}: \mathrm{L}=2: 3$ chelate was formed.

The furazan of 4-t-butyl-1,2,6-cyclohexanetrione trioxime (HFBHT)

HFBHT can also be called 6 - $t$ - butyl - 4 hydroxyimino - 4,5,6,7 - tetrahydrobenzofurazan in analogy with Lewis ${ }^{15}$ (the same molecule without $t$-butyl group) or 6,7-dihydro-6-t-butylbenzofurazan- $4(5 \mathrm{H})$-one oxime in similarity with Calleri $^{16}$ (the same molecule with a dimethyl group instead of a $t$-butyl group). Other names for this compound could use a 1,2,5-oxadiazole ring as basis.

HFBHT is not very soluble in water, but dissolves very well in organic solvents like ethanol and ether. This can be explained by the hydrophobic $t$-butyl group and by the fact that two of the three polar oxime groups are now transformed in an 
organic furazan ring. The $\mathrm{N}-\mathrm{N}$ distance between the nitrogen of the oxime group and the nitrogen of the furazan can be calculated from the values of the atomic coordinates found by Calleri ${ }^{16}$ for a similar molecule. The $\mathrm{N}-\mathrm{N}$ distance is calculated to be $2.835 \AA$ and such a distance makes $\mathbf{N}, \mathbf{N}$-coordination the most likely one. Furthermore Calleri's X-ray analysis showed that the oxime group is anti in respect to the furazan. Nevertheless no extraction properties are found for this ligand. The reason for this is, most likely, that the furazan possesses such a poor complexing capacity (Driessen ${ }^{17}$ found poor complexing capacities for furazans) that even with a strong complexing neighbour as the oxime group no bidentate reaction with metal ions takes place under extraction conditions. Another reason may be that a furazan oxime chelate cannot have hydrogen bridge stabilization, like dioxime chelates, because the oxime group will be deprotonated by the extraction reaction:

$$
\mathrm{M}^{2+}+2 \mathrm{HFBHT} \rightleftarrows \mathrm{M}(\mathrm{FBHT})_{2}+2 \mathrm{H}^{+} .
$$

The conclusion that can be drawn from these results is that furazan oximes are of no use for extraction of $\mathrm{Cu}(\mathrm{II})$ and $\mathrm{Ni}(\mathrm{II})$.

\section{CONCLUSIONS}

$\mathrm{H}_{3} \mathrm{CPT}$ is more soluble in water than in organic solvents, which makes this compound of no use as an extractant. This ligand is able to form chelates with copper and nickel which precipitate in the water layer. The introduction of a large hydrophobic group into the aliphatic ring, like $t$-butyl in $\mathrm{H}_{3} \mathrm{BHT}$, provides an answer to this solubility problem.

$\mathrm{Ni}(\mathrm{II})$ was extracted by $\mathrm{H}_{3} \mathrm{CBHT}$ as $\mathrm{Ni}\left(\mathrm{H}_{2} \mathrm{BHT}\right)_{2}$, but this chelate precipitated in the organic layer and therefore blocked the back extraction. This is caused by intermolecular hydrogen bridge formation and/or coordination of the third oxime group, which is not primarily involved in the chelation with nickel. The $\mathrm{Cu}$ (II) extraction by excess $\mathrm{H}_{3} \mathrm{BHT}$ showed the same picture with the precipitation of $\mathrm{Cu}\left(\mathrm{H}_{2} \mathrm{BHT}\right)_{2} \cdot 2 \mathrm{H}_{2} \mathrm{O}$. When the extraction is performed with excess copper ions a $\mathrm{Cu}: \mathrm{H}_{3} \mathrm{BHT}=1: 1$ chelate is formed which is soluble in the organic layer. The third oxime group is now directly involved in the chelation with copper and no intermolecular hydrogen bridge formation can occur. These results show that the use of trioximes for the extraction of $\mathrm{Cu}$ (II) and $\mathrm{Ni}(\mathrm{II})$ is not an improvement with respect to the dioximes but, on the contrary, is a step backwards because new problems, like precipitation and blocked back extraction, are introduced.

The experiments with the two furazan oximes confirm the conclusion that a large hydrophobic group like $t$-butyl changes the solubility properties in the desired direction. Furthermore, it is shown that this type of ligand is not suitable for extraction of copper and nickel ions because under extraction conditions no chelates with copper and nickel are formed. The reasons for this are that furazan is too weak a ligand and that no hydrogen bridge stabilization is possible after chelation.

\section{REFERENCES}

1. L. R. M. Paping, T. P. M. Beelen, C. P. J. Rummens and R. Prins, Polyhedron 1982, 1, 503.

2. L. R. M. Paping, T. P. M. Beelen, M. Mols and R. Prins, Polyhedron, submitted for publication.

3. J. W. Frierson and N. Marable, Anal. Chem. 1962, 34, 210.

4. A. F. Ferris, G. S. Johnson, F. E. Gould and H. K. Latourette, J. Org. Chem. 1960, 25, 492.

5. H. M. Swartz, J. R. Bolton and D. C. Borg, Biol. appl. of Elect. Spin Reson. 1972.

6. J. F. Barnes, M. J. Barrow, M. M. Harding, R. M. Paton, P. L. Ashcroft, J. Crosby and C. J. Joyce, J. Chem. Research (S) 1979, 314.

7. V. Peshkova, V. Savostina and E. AstakhovaIvanova, Solvent Extraction Chem. Proc. Int. Conf. Goteborg, p.66 (1966).

8. A. Nakamura, A. Konishi and S. Otsuka, J.C.S. Dalton 1979, 488.

9. M. S. Ma and R. J. Angelici, Inorg. Chem. 1980, 19, 363.

10. B. J. Hathaway and D. E. Billing, Coord. Chem. Rev. 1970, 59, 143.

11. J. A. Bertrand, J. H. Smith and P. G. Eller, Inorg. Chem. 1975, 13, 1649.

12. D. E. Fenton and R. L. Lindtvedt, J. Am. Chem. Soc. 1978, 100, 6367.

13. J. Reedijk and R. W. M. ten Hoedt, Rec. Trav. Chim. 1982, 101, 49.

14. O. Kahn, Inorg. Chim. Acta 1982, $62,3$.

15. J. J. Lewis, J. Heterocycl. Chem. 1975, 12, 601.

16. M. Calleri and G. Chiari, Acta Cryst. 1978, B34, 2953.

17. W. L. Driessen and P. L. A. Everstijn, Z. Naturforsch. 1978, 33B, 1120. 